\title{
Multiplex preamplification of specific cDNA targets prior to gene expression analysis by TaqMan Arrays Lourdes Mengual*1,2, Moisès Burset ${ }^{1,2}$, Mercedes Marín-Aguilera1,2, María José Ribal ${ }^{1}$ and Antonio Alcaraz ${ }^{1}$
}

Address: ${ }^{1}$ Laboratory and Department of Urology. Institut Clínic de Nefrologia i Urologia (ICNU), Hospital Clínic de Barcelona. Institut d'Investigacions Biomèdiques August Pi i Sunyer (IDIBAPS), Universitat de Barcelona, Villarroel, 170, 08036 Barcelona, Spain and ${ }^{2}$ Molecular Biology Laboratory. Fundació Puigvert. Universitat Autònoma de Barcelona, Cartagena 340-350, 08025 Barcelona, Spain

Email: Lourdes Mengual* - lmengual@ub.edu; Moisès Burset - mburset@gmail.com; Mercedes Marín-Aguilera - mermarin@gmail.com; María José Ribal - mjribal@clinic.ub.es; Antonio Alcaraz - aalcaraz@clinic.ub.es

* Corresponding author

Published: 5 June 2008

BMC Research Notes 2008, I:2I doi:10.1/86/1756-0500-I-2I
Received: 26 February 2008

Accepted: 5 June 2008

This article is available from: http://www.biomedcentral.com/1756-0500/I/2I

(C) 2008 Mengual et al; licensee BioMed Central Ltd.

This is an Open Access article distributed under the terms of the Creative Commons Attribution License (http://creativecommons.org/licenses/by/2.0), which permits unrestricted use, distribution, and reproduction in any medium, provided the original work is properly cited.

\begin{abstract}
Background: An accurate gene expression quantification using TaqMan Arrays (TA) could be limited by the low RNA quantity obtained from some clinical samples. The novel cDNA preamplification system, the TaqMan PreAmp Master Mix kit (TPAMMK), enables a multiplex preamplification of cDNA targets and therefore, could provide a sufficient amount of specific amplicons for their posterior analysis on TA.
\end{abstract}

Findings: A multiplex preamplification of 47 genes was performed in 22 samples prior to their analysis by TA, and relative gene expression levels of non-preamplified (NPA) and preamplified (PA) samples were compared. Overall, the mean cycle threshold (CT) decrement in the PA genes was 3.85 (ranging from 2.07 to 5.0 I). A high correlation ( $r$ ) between the gene expression measurements of NPA and PA samples was found (mean $r=0.970$, ranging from 0.937 to $0.994 ; p<0.001$ in all selected cases). High correlation coefficients between NPA and PA samples were also obtained in the analysis of genes from degraded RNA samples and/or low abundance expressed genes.

Conclusion: We demonstrate that cDNA preamplification using the TPAMMK before TA analysis is a reliable approach to simultaneously measure gene expression of multiple targets in a single sample. Moreover, this procedure was validated in genes from degraded RNA samples and low abundance expressed genes. This combined methodology could have wide applications in clinical research, where scarce amounts of degraded RNA are usually obtained and several genes need to be quantified in each sample.

\section{Findings}

\section{Background}

TaqMan Arrays (TAs) have recently been introduced as a novel approach to measure gene expression. They combine the high sensitivity provided by the real time quantitative reverse-transcription polymerase chain reaction
(qRT-PCR) with the ability to simultaneously assay RNA expression levels of up to 384 target genes in a single sample $[1,2]$. However, an accurate quantification with this approach could be limited by the low sample amount commonly encountered in clinical research. Therefore, it is necessary to preamplify samples to generate enough 
cDNA copies to enable an accurate quantification of transcripts and maintain high sensitivity.

Most of the current protocols for increasing small amounts of mRNA are designed to globally amplify all the transcriptome instead of the specific targets of interest and are usually validated by DNA array, which is a more imprecise methodology than qRT-PCR to quantify individual genes $[3,4]$.

Recently, a novel system, the TPAMMK, to increase cDNA quantity prior to gene expression analysis by conventional quantitative PCR has been described [5-8]. However, there is no study validating this approach prior to gene expression quantification by means of TA. The possibility of simultaneously measuring gene expression of dozens to hundreds of genes in those samples that yield scarce quantities of RNA would be of great interest.

Here, we evaluate this cDNA preamplification system (TPAMMK) prior to gene expression quantification by TA. We test the approach in the context of bladder cancer detection, by analyzing RNA samples obtained from bladder fluids. Furthermore, this type of sample provides us the possibility to analyze the reliability of this combined methodology for preamplifying cDNA from degraded RNA samples and/or low abundance expressed genes.

\section{Results and discussion}

One of the major drawbacks for the clinical use of RNA based techniques is the difficulty of obtaining sufficient quantities of high quality RNA from some human samples. The novel multiplexed miniaturized format provided by TAs could be limited by the scarce quantities of isolated RNA, since the sample is divided into a large number of aliquots [9]. Several strategies for amplifying RNA [10-12] or cDNA have been described [5-8,13,14], but to date, there is no published study validating that cDNA preamplification prior to TA analysis provides a reliable representation of gene expression profiling.

In this study, we have used the TPAMMK (AB) to preamplify 47 genes in 22 bladder fluids samples prior to their analysis by TA. This preamplification process allowed us to load a 30 fold greater quantity of cDNA in each TA port (500 ng for NPA $v s \sim 15000 \mathrm{ng}$ for PA samples) which should theoretically result in a decrement of 4.9 CTs. However, we found an overall mean CT decrement of 3.85 (ranging from 2.07 to 5.01) in PA samples (Table 1). Although variations in amplification efficiencies (AE) of the primers/probe sets used in TA methodology have been found in this study and others [1], they do not help to explain differences between the theoretical and the experimental CT decrement described, since there is no significant correlation between the experimental CT decrement and the primers/probe set $\mathrm{AE}$, neither before $(\mathrm{r}=0.062 ; \mathrm{P}$ $=0.678)$ nor after $(\mathrm{r}=0.060 ; \mathrm{p}=0.097)$ the $\mathrm{CDNA}$ preamplification process (Table 1 ).

On the other hand, linear regression analysis showed a high correlation (r) between gene expression measurements of NPA and PA samples for the validated genes (mean $\mathrm{r}$ values $=0.970$, ranging from 0.937 to $0.994, \mathrm{p}<$ 0.001 in all cases, except for sample number 15 where only 3 genes could be analyzed) (Table 2). Thus, albeit CT decrement for each individual gene is not uniform, the overall relative gene expression levels in PA samples remained proportional to the original gene expression levels in NPA samples. However, when checking preamplification uniformity individually for each gene $(\Delta \Delta \mathrm{CT}$ values within \pm 1.5 ) we found that there were three genes (IGF2, FGFR3 and CRH) that were consistently non-uniformly preamplified in a significant number of samples and therefore were not suitable for preamplification (Table 2). We do not have a clear explanation for this fact, although transcript abundance, primers and probe localization or amplicon length/sequence could influence the preamplification efficiency. From these results, it becomes clear that cDNA preamplification before gene expression quantification by TA can facilitate the analysis of multiple target genes from very low quantities of RNA in a single experiment. However, checking the preamplification uniformity in each target gene with control material before its evaluation in testing samples is mandatory.

As the described CT decrement would not be sufficient to accurately quantify gene expression in some cases, it must be mentioned that, according to kit manufacturers, it is possible to perform up to 14 preamplification cycles, as well as to increase the quantity of cDNA in the preamplification reaction up to $250 \mathrm{ng}$ or to load more preamplified volume of cDNA into each TA port to achieve the desired decrement.

Since our goal was to test the suitability of the cDNA preamplification of specific target genes before their quantification by TA, we have only analyzed those genes with a reliable CT value in NPA samples $(\mathrm{CT} \geq 31)$. However, to determine the linearity of the cDNA preamplification in low abundant expressed genes (those target genes with a CT value > 31 in NPA samples), we performed two serial dilutions (1/20 and 1/400) of 3 cDNAs from NPA samples with different RNA degradation levels (sample number 2, 11 and 22) and preamplified them with the same protocol used for the non diluted NPA samples. Subsequently, we compared the $\Delta \mathrm{CT}$ values from diluted PA samples with the corresponding $\Delta \mathrm{CT}$ of the initial cDNA (non diluted NPA) samples. This comparison yielded correlation coefficients close to 1 , indicating that the vast majority of low abundant expressed genes are cor- 
Table I: Mean CT and mean AE for the 46 bladder cancer related genes and the endogenous control GUSB obtained before and after cDNA preamplification.

\begin{tabular}{|c|c|c|c|c|c|c|c|c|c|c|c|c|c|}
\hline \multirow{2}{*}{$\begin{array}{l}\text { Gene } \\
\text { symbol }\end{array}$} & \multirow{2}{*}{$\begin{array}{l}\text { Primer/probe set } \\
\text { (AB) }\end{array}$} & \multicolumn{2}{|c|}{ Validated samples } & \multicolumn{2}{|c|}{ NPA samples } & \multicolumn{2}{|c|}{ PA samples } & \multirow{2}{*}{$\begin{array}{c}\text { Mean } C_{t} \\
\text { decrement }\end{array}$} & \multirow[t]{2}{*}{$\mathbf{r}$} & \multicolumn{2}{|c|}{ NPA samples } & \multicolumn{2}{|c|}{ PA samples } \\
\hline & & n NPA & n PA & Mean Ct & St Dev & Mean Ct & St Dev & & & Mean AE & St Dev & Mean AE & St Dev \\
\hline ANK2 & Hs00I53998_ml & I & 18 & 29,22 & - & 25,90 & - & 3,32 & - & 1,889 & - & 1,794 & - \\
\hline ANLN & Hs002I8803_ml & 17 & 20 & 28,50 & 1,58 & 23,97 & 1,64 & 4,53 & 0,966 & I,807 & 0,06 & 1,834 & 0,09 \\
\hline ANXAIO & Hs00200464_ml & 16 & 20 & 27,19 & 2,83 & 22,87 & 2,45 & 4,32 & 0,992 & I,987 & 0,05 & 1,962 & 0,08 \\
\hline ASAM & Hs00293345_ml & 3 & 15 & 29,39 & $\mathrm{I}, 08$ & 25,31 & 0,93 & 4,09 & 0,965 & 1,926 & - & 1,752 & - \\
\hline ASPM & Hs004II505_ml & 16 & 21 & 27,88 & 1,63 & 23,93 & $\mathrm{I}, 52$ & 3,95 & 0,978 & 1,897 & 0,05 & $\mathrm{I}, 838$ & 0,09 \\
\hline CI4orf78 & Hs00746838_sl & 16 & 22 & 28,65 & $\mathrm{I}, 78$ & 24,56 & $\mathrm{I}, 52$ & 4,09 & 0,991 & 1,933 & 0,06 & 1,796 & 0,09 \\
\hline CCNA2 & $\mathrm{Hs} 00 \mathrm{I} 53 \mathrm{I} 38$ ml & 17 & 20 & 28,65 & $\mathrm{I}, 78$ & 25,22 & $\mathrm{I}, 74$ & 3,42 & 0,93 & $|, 82|$ & 0,03 & 1,688 & 0,06 \\
\hline$C D C 2$ & Hs00364293_ml & 16 & 20 & 28,47 & $\mathrm{I}, 77$ & 23,86 & $\mathrm{I}, 74$ & 4,61 & 0,96 & $\mathrm{I}, 867$ & 0,06 & $\mathrm{I}, 823$ & 0,09 \\
\hline CDC20 & Hs004I585I_gl & 20 & 20 & 28,09 & 2,19 & 24,09 & 2,12 & 4,01 & 0,973 & 1,816 & 0,05 & I,803 & 0,09 \\
\hline CDCAI & Hs00230097_ml & 13 & 20 & 28,76 & $\mathrm{I}, 40$ & 24,37 & 1,26 & 4,40 & 0,944 & $\mathrm{I}, 944$ & 0,02 & I,768 & 0,10 \\
\hline CENPF & Hs00I9320I_ml & 16 & 21 & 28,20 & 1,65 & 24,55 & $\mathrm{I}, 58$ & 3,65 & 0,96 & 1,898 & 0,04 & $\mathrm{I}, 840$ & 0,10 \\
\hline CFH & Hs00164830_ml & 19 & 22 & 26,66 & 2,40 & 22,71 & 2,15 & 3,95 & 0,978 & $\mathrm{I}, 832$ & 0,04 & 1,786 & 0,02 \\
\hline $\mathrm{CRH}$ & Hs00I7494I_ml & 9 & 11 & 25,42 & 2,67 & 23,01 & 2,31 & 2,40 & 0,967 & 1,836 & 0,06 & $1,7 \mid 1$ & 0,11 \\
\hline CTSE & Hs00I572I3_ml & 19 & 21 & 25,60 & 3,52 & 21,38 & 3,38 & 4,22 & 0,997 & 1,858 & 0,05 & $\mathrm{I}, 842$ & 0,03 \\
\hline CYP24AI & Hs00I67999_ml & 19 & 21 & 26,40 & 3,11 & 22,62 & 2,93 & 3,78 & 0,994 & 1,944 & 0,07 & 1,940 & 0,08 \\
\hline$E B F$ & Hs003955I3_ml & 3 & 14 & 29,87 & 0,67 & 26,27 & 0,44 & 3,60 & 0,817 & 1,665 & - & $|, 65|$ & - \\
\hline FGFR3 & Hs00I79829_ml & 18 & 20 & 23,88 & 2,76 & 21,26 & 2,67 & 2,62 & 0,967 & I,833 & 0,04 & $\mathrm{I}, 753$ & 0,07 \\
\hline FOXMI & Hs00153543_ml & 15 & 20 & 28,38 & 2,00 & 24,67 & $\mathrm{I}, 88$ & 3,71 & 0,971 & I,896 & 0,05 & 1,718 & 0,05 \\
\hline GJB2 & Hs002696I5_sl & 21 & 22 & 26,13 & 2,39 & 22,27 & 2,36 & 3,86 & 0,984 & $\mathrm{I}, 864$ & 0,05 & 1,888 & 0,06 \\
\hline GUSB & Hs99999908_ml & 22 & 22 & 25,18 & 2,08 & 20,79 & 2,14 & 4,40 & - & 1,914 & 0,04 & 1,942 & 0,07 \\
\hline IGF2 & Hs00I7I254_ml & 18 & 21 & 25,15 & 3,98 & 23,08 & 3,90 & 2,07 & 0,993 & 1,835 & 0,06 & $\mathrm{I}, 743$ & 0,07 \\
\hline IQGAP3 & Hs00603642_ml & 14 & 20 & 28,29 & 1,52 & 24,18 & $\mathrm{I}, 49$ & $4, I I$ & 0,978 & 1,886 & 0,03 & 1,782 & 0,04 \\
\hline KIF2OA & Hs00194882_ml & 12 & 20 & 28,11 & $\mathrm{I}, 47$ & 24,26 & $\mathrm{I}, 47$ & 3,85 & 0,982 & 1,905 & 0,03 & 1,786 & 0,08 \\
\hline KIF2C & $\mathrm{Hs} 00199232 \_\mathrm{ml}$ & 17 & 21 & 27,97 & $\mathrm{I}, 87$ & 23,88 & 1,93 & 4,09 & 0,966 & $\mathrm{I}, 804$ & 0,05 & 1,739 & 0,06 \\
\hline KIF4A & $\mathrm{Hs} 006022 \mathrm{II} / \mathrm{gl}$ & 13 & 20 & 28,27 & 1,56 & 24,02 & 1,37 & 4,25 & 0,968 & $\mathrm{I}, 872$ & 0,07 & 1,797 & 0,08 \\
\hline KLF9 & Hs002309l8_ml & 21 & 22 & 27,60 & 1,66 & 23,65 & $\mathrm{I}, 54$ & 3,95 & 0,955 & 1,793 & 0,08 & 1,805 & 0,07 \\
\hline KRTI4 & Hs00265033_ml & 12 & 20 & 29,12 & 1,34 & 25,66 & $\mathrm{I}, 54$ & 3,45 & 0,97 & 1,995 & 0,08 & $\mathrm{I}, 780$ & 0,15 \\
\hline KRT20 & Hs00300643_ml & 19 & 21 & 23,21 & 3,05 & 19,54 & 2,84 & 3,66 & 0,986 & $\mathrm{I}, 977$ & 0,05 & 2,019 & 0,08 \\
\hline MAGEA3 & Hs00366532_ml & 5 & 8 & 28,01 & 0,44 & 24,50 & 0,73 & 3,51 & 0,935 & $\mathrm{I}, 790$ & 0,05 & $\mathrm{I}, 747$ & 0,03 \\
\hline MAGEA9 & Hs00245619_sl & 13 & 21 & 27,44 & $\mathrm{I}, 74$ & 23,99 & 1,66 & 3,45 & 0,986 & $\mathrm{I}, 874$ & 0,02 & 1,736 & 0,07 \\
\hline MCMIO & Hs002I8560_ml & 9 & 20 & 28,82 & 1,09 & 25,16 & 1,12 & 3,66 & 0,968 & $|, 86|$ & 0,03 & 1,694 & 0,03 \\
\hline MELK & Hs0020768I_ml & 13 & 20 & 28,33 & 1,58 & 24,83 & 1,60 & 3,50 & 0,932 & $|, 82|$ & 0,07 & $|, 67|$ & 0,10 \\
\hline$M M P I$ & Hs00233958_ml & 18 & 21 & 26,04 & 2,92 & 22,34 & 2,91 & 3,71 & 0,986 & 1,686 & 0,06 & 1,640 & 0,07 \\
\hline MMPI2 & Hs00I59l78_ml & 12 & 18 & 28,19 & 2,17 & 23,17 & 2,11 & 5,01 & 0,987 & 1,846 & 0,11 & 1,818 & 0,09 \\
\hline NEK2 & $\mathrm{Hs} 0060 \mathrm{I} 227 \_\mathrm{mH}$ & 12 & 21 & 28,78 & 1,56 & 24,39 & $\mathrm{I}, 47$ & 4,38 & 0,963 & $\mathrm{I}, 737$ & 0,06 & $\mathrm{I}, 773$ & 0,09 \\
\hline $\mathrm{NR} 2 \mathrm{FI}$ & Hs008I8842_ml & 6 & 19 & 29,08 & 1,52 & 24,77 & $\mid, 5 \mathrm{I}$ & 4,31 & 0,984 & 1,845 & 0,05 & 1,790 & 0,01 \\
\hline PDZRN3 & Hs00392900_ml & 10 & 22 & 26,72 & 2,07 & 23,11 & $\mathrm{I}, 74$ & 3,61 & 0,99 & 1,888 & 0,05 & 1,736 & 0,11 \\
\hline POLQ & $\mathrm{Hs} 00198196 \_m l$ & 10 & 19 & 29,47 & 1,09 & 24,98 & $\mathrm{I}, 20$ & 4,49 & 0,914 & $\mathrm{I}, 807$ & 0,07 & 1,608 & 0,15 \\
\hline POSTN & Hs00I708I5_ml & 4 & 12 & 28,96 & $\mathrm{I}, 45$ & 24,70 & $\mathrm{I}, 47$ & 4,26 & 0,983 & 1,904 & 0,09 & $\mathrm{I}, 837$ & 0,12 \\
\hline PPIA & Hs99999904_ml & 22 & 22 & 21,54 & 2,32 & 17,76 & 2,29 & 3,78 & 0,927 & 1,912 & 0,04 & I,99| & 0,10 \\
\hline PPPIR/4D & $\mathrm{Hs} 002 \mathrm{I} 46 \mathrm{I}$ _ml & 8 & 18 & 28,18 & 2,05 & 24,29 & $\mathrm{I}, 68$ & 3,89 & 0,989 & $\mathrm{I}, 886$ & 0,07 & $\mathrm{I}, 833$ & 0,14 \\
\hline PTPRC & Hs00236304_ml & 22 & 22 & 25,15 & 2,03 & 21,62 & 2,18 & 3,53 & 0,986 & 1,944 & 0,06 & 1,886 & 0,09 \\
\hline SLCIAG & Hs00192604_ml & 7 & 12 & 27,54 & 2,05 & 23,63 & $\mathrm{I}, 34$ & 3,92 & 0,978 & 1,743 & 0,03 & 1,683 & 0,02 \\
\hline TERT & $\mathrm{Hs} 00 \mathrm{I} 62669 \_\mathrm{ml}$ & 2 & 12 & 29,40 & $\mathrm{I}, 13$ & 26,10 & $\mathrm{I}, 64$ & 3,31 & - & 1,856 & - & 1,697 & - \\
\hline TOP2A & $\mathrm{Hs00I722I4 \_ ml}$ & 19 & 20 & 27,40 & 2,42 & 23,31 & 2,27 & 4,09 & 0,909 & 1,890 & 0,06 & 1,873 & 0,09 \\
\hline TPX2 & $\mathrm{Hs} 00201616 \_m l$ & 18 & 20 & 27,69 & 2,17 & 23,91 & 2,04 & 3,78 & 0,968 & 1,990 & 0,07 & I,931 & 0,07 \\
\hline TRIPI3 & Hs00I88500_ml & 18 & 20 & 28,03 & 1,96 & 23,83 & $\mathrm{I}, 90$ & 4,21 & 0,976 & $\mathrm{I}, 893$ & 0,05 & 1,806 & 0,05 \\
\hline
\end{tabular}




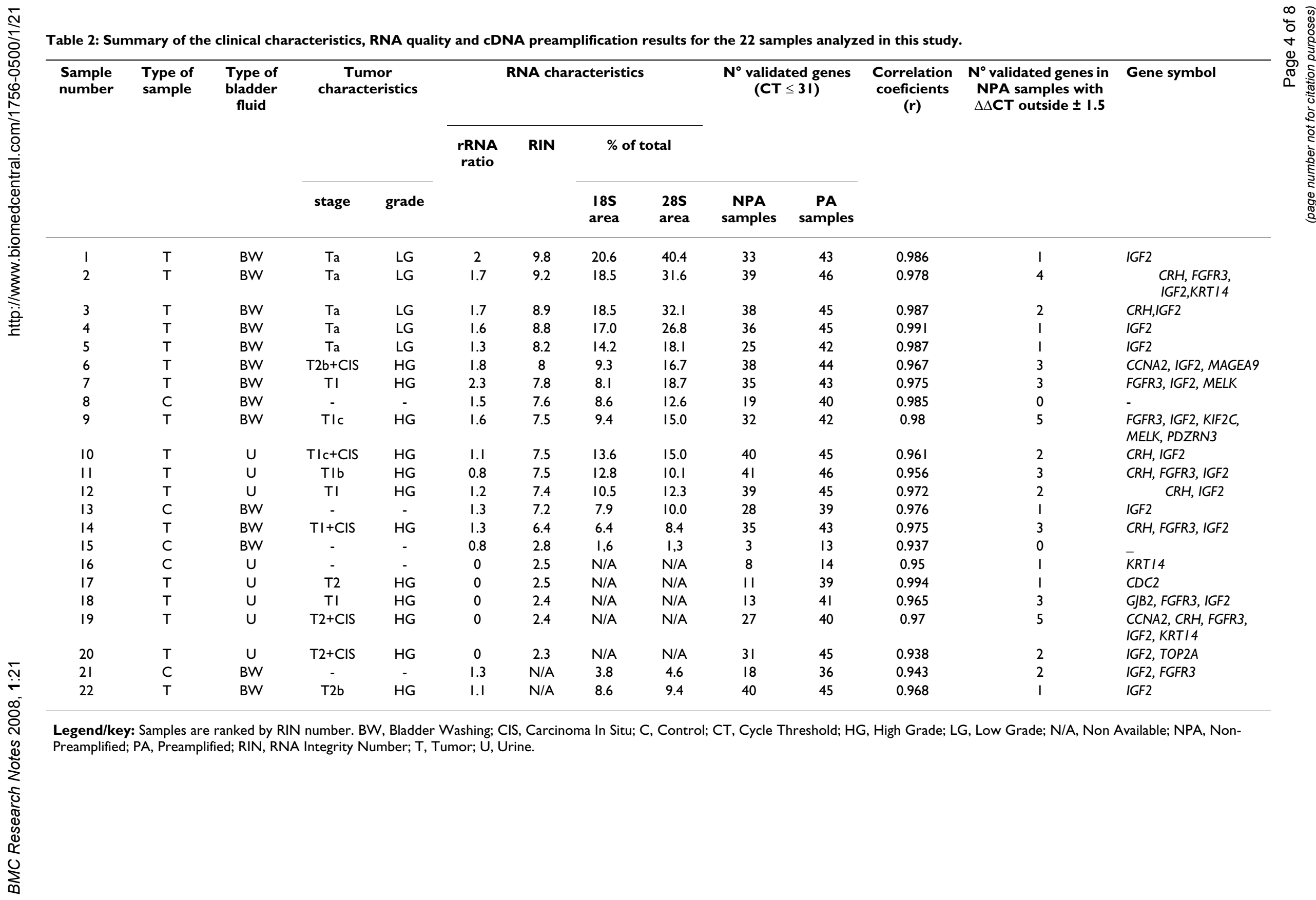


rectly preamplified and that the preamplification process maintains relative gene expression levels of the initial RNA over a broad range of CT values (Table 3 ).

For some time, it has been believed that degraded RNA samples were not suitable for gene expression studies. Nevertheless, many authors have recently reported the use of this material for gene profiling using DNA microarrays as well as qRT-PCR approaches $[12,15]$. In order to investigate whether RNA degradation influences the efficiency of preamplification, gene expression measurements from those samples with a high RNA quality (RIN $>8 ; \mathrm{n}=6)$, those with good RNA quality $(5<$ RIN $<8 ; \mathrm{n}=8)$ and those with low RNA quality (RIN $<5 ; \mathrm{n}=6$ ) [16] were compared (Table 2). The two samples with non available RIN were excluded from this part of the study. The mean CT decrement after preamplification was very similar in the three groups of samples; 3.90, 3.68 and 4.00, respectively. As expected, we initially found that the average number of validated genes corresponds to the RNA integrity (35.8, 34.6 and 16.5 in high, good and low RNA quality samples, respectively). The average number of validated genes

Table 3: Number of validated genes of two serial dilutions of 3 cDNA samples before and after their preamplification.

\begin{tabular}{|c|c|c|c|c|}
\hline \multirow{4}{*}{ Sample number } & \multicolumn{4}{|c|}{ Initial cDNA } \\
\hline & \multicolumn{4}{|c|}{25 ng of preamplified cDNA } \\
\hline & \multicolumn{2}{|c|}{$\mathrm{N}^{\circ}$ validated genes $(\mathrm{CT} \leq 3 \mathrm{I})$} & \multirow[t]{2}{*}{$\mathrm{N}^{\circ}$ validated genes with $\Delta \Delta \mathrm{CT}$ outside $\pm \mathrm{I} .5$} & \multirow[t]{2}{*}{ r } \\
\hline & NPA samples & PA samples & & \\
\hline 2 & 39 & 46 & 4 & 0.978 \\
\hline 11 & 41 & 46 & 3 & 0.956 \\
\hline 22 & 40 & 45 & 1 & 0.968 \\
\hline ng cDNA/port & 500 & 15000 & & \\
\hline
\end{tabular}

Dilution $\mathrm{I} / 20$ of the initial cDNA

\begin{tabular}{|c|c|c|c|c|}
\hline \multirow{3}{*}{ Sample number } & \multicolumn{4}{|c|}{ I.25 ng of preamplified cDNA } \\
\hline & \multicolumn{2}{|c|}{$\mathrm{N}^{\circ}$ validated genes $(\mathrm{CT} \leq 3 \mathrm{I})$} & \multirow[t]{2}{*}{$\mathrm{N}^{\circ}$ validated genes with $\Delta \Delta \mathrm{CT}$ outside \pm 1.5} & \multirow[t]{2}{*}{$r$} \\
\hline & NPA samples & PA samples & & \\
\hline 2 & 14 & 38 & 6 & 0.972 \\
\hline 11 & 22 & 40 & 2 & 0.967 \\
\hline 22 & 6 & 39 & 5 & 0.988 \\
\hline ng cDNA/port & 25 & 750 & & \\
\hline
\end{tabular}

Dilution I/400 of the initial cDNA

\begin{tabular}{|c|c|c|c|c|}
\hline \multirow{3}{*}{ Sample number } & \multicolumn{4}{|c|}{$0.06 \mathrm{ng}$ of preamplified cDNA } \\
\hline & \multicolumn{2}{|c|}{$\mathrm{N}^{\circ}$ validated genes $(\mathrm{CT} \leq 3 \mathrm{I})$} & \multirow[t]{2}{*}{$\mathrm{N}^{\circ}$ validated genes with $\Delta \Delta \mathrm{CT}$ outside $\pm \mathrm{I} .5$} & \multirow[t]{2}{*}{$r$} \\
\hline & NPA samples & PA samples & & \\
\hline 2 & 3 & 17 & 0 & 0.962 \\
\hline 11 & 2 & 27 & 3 & 0.883 \\
\hline 22 & 3 & 20 & 2 & 0.932 \\
\hline ng cDNA/port & 1.25 & 37.5 & & \\
\hline
\end{tabular}

Legend/key: The number of each sample corresponds to the "sample number" indicated in Table 2. CT, Cycle Threshold; NPA, Non-Preamplified; PA, Preamplified. 
in the three groups of samples after the cDNA preamplification was 45.2, 43.9 and 32.8 in high, good and low RNA quality samples, respectively, resulting from the increment in the number of validated genes being much higher in degraded RNA than from high/good quality RNA samples.

Thus, we have been able to demonstrate that preamplifed cDNA from samples with different RNA degradation states is a suitable material for TA analysis, facilitating the simultaneous analysis of multiple targets in a single experiment from archived pathology specimens in retrospective studies.

\section{Conclusion}

To our knowledge, this is the first quantitative gene expression report validating that cDNA preamplification using the TPAMMK prior to TA analysis preserves relative transcript expression levels of individual genes. The possibility to increase cDNA quantity before its analysis by TA opens up the possibility of analysing multiple target genes in a single experiment in those samples that yield scarce quantities of RNA. Furthermore, this approach is suitable for preamplifying genes from degraded RNA and low abundance expressed genes. This combined methodology could have wide applications in clinical research, where scarce amounts of degraded RNA are usually obtained and several genes needs to be quantified in each sample.

\section{Methods}

\section{Patients and samples}

Ten bladder washings (BW) and 7 voided urine specimens from patients with pathologically diagnosed bladder cancer (BC) $[17,18]$ and $4 \mathrm{BW}$ and 1 urine sample from patients without history of BC (controls) were collected between April 2004 and September 2005 after informed consent (Table 2).

Ice cooled BW or urine samples were mixed with $1 / 25$ volumes of 0.5 M EDTA, $\mathrm{pH} 8.0$ and were centrifuged at 1000 $\times \mathrm{g}$ for 10 minutes. The cell pellets were re-suspended in 1 $\mathrm{ml}$ of TRIzol reagent (Invitrogen, Carlsbad, CA, USA) and frozen at $-80^{\circ} \mathrm{C}$ until RNA extraction.

\section{RNA extraction and CDNA synthesis}

RNAs were extracted using TRIzol reagent (Invitrogen, Carlsbad, CA, USA) according to manufacturer's instructions. Total RNA was quantified by spectrophotometric analysis at $260 \mathrm{~nm}$ and RNA degradation was assessed using the Agilent 2100 Bioanalyzer (Agilent Technologies, Waldbronn, Germany) [19] (Table 2).

cDNA was synthesized from $1 \mu \mathrm{g}$ of total RNA using the High Capacity cDNA Archive Kit (Applied Biosystems, Foster City, USA, hereafter referred as AB) following man- ufacturer instructions, except that the final volume of the reaction was $50 \mu \mathrm{l}$.

\section{Multiplex preamplification of CDNA targets}

A multiplex PCR preamplification of the 46 specific cDNA targets and the endogenous control GUSB (Table 1) was performed using TPAMMK following manufacturer's instructions (AB). The 47 TaqMan Gene Expression Assays $(\mathrm{AB})$ were pooled together at $0.2 \times$ final concentration. Subsequently, $12.5 \mu \mathrm{l}$ of the pooled assay mix (0.2X) were combined with $25 \mathrm{ng}$ of each cDNA sample and $25 \mu \mathrm{l}$ of the TaqMan PreAmp Master Mix (2X) in a final volume of $50 \mu \mathrm{l}$ (Figure 1). Thermal cycling conditions were as follows: initial hold at $95^{\circ} \mathrm{C}$ during $10 \mathrm{~min}$ and ten preamplification cycles of $15 \mathrm{sec}$ at $95^{\circ} \mathrm{C}$ and $4 \mathrm{~min}$ at $60^{\circ} \mathrm{C}$.

For samples $n^{\circ} 2,11$ and 22, two dilutions (1/20 and $1 /$ $400)$ of the NPA cDNA were prepared and $1.25 \mu \mathrm{l}$ of each cDNA dilution ( $1.25 \mathrm{ng}$ and $0.0625 \mathrm{ng}$, respectively) were subsequently preamplified with the same protocol described above.

\section{TaqMan Arrays (TA)}

The NPA and PA target cDNAs were then amplified in singleplex reactions using TA following manufacturer's rec-

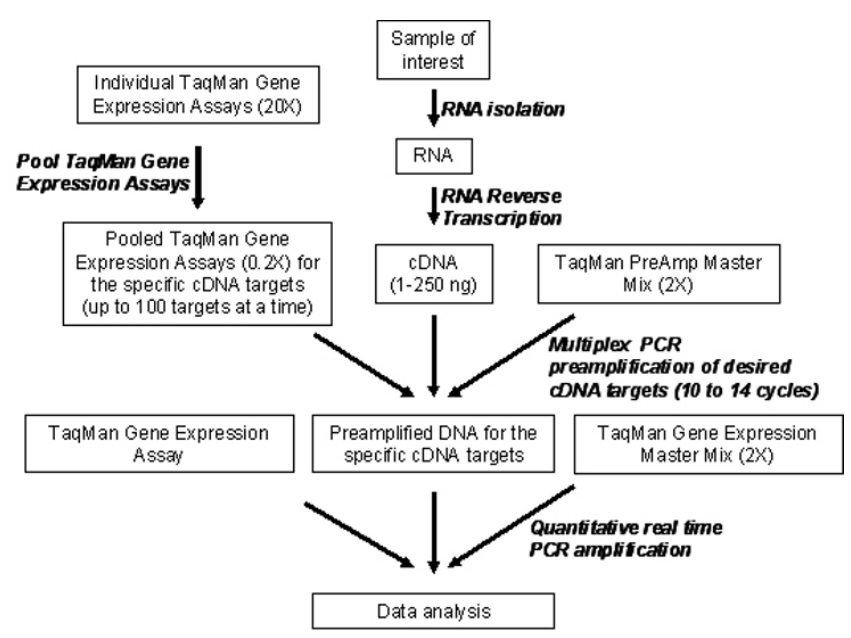

\section{Figure I}

Workflow for the entire preamplification process. Detailed steps are described in the Material and Methods section. Briefly, to increase the quantity of the specific cDNA targets for gene expression analysis using TaqMan methodology, cDNA from the reverse transcription is mixed with pooled TaqMan Gene Expression Assays and with TaqMan PreAmp MasterMix. After the multiplex preamplification of desired cDNA targets, quantitative real time PCR amplification of preamplified target cDNAs, using sequence-specific primers and TaqMan probes from the TaqMan Gene Expression Assays and TaqMan Gene Expression Master Mix, is performed. 
ommendations (AB). Commercially available TaqMan Gene Expression Assays (AB) for all the 46 genes differentially expressed in bladder cancer specimens (data not shown) and the endogenous control GUSB were used (Table 1). Twenty-five $\mu \mathrm{l}$ of NPA cDNAs and $30 \mu \mathrm{l}$ of PA cDNAs were mixed with $50 \mu \mathrm{l}$ of $2 \times$ TaqMan Universal PCR Master Mix (AB) in a final volume of $100 \mu$ l. After loading mixes into the TA ports, cards were centrifuged twice for $1 \mathrm{~min}$ at $1200 \mathrm{rpm}$, sealed and run in an ABI PRISM 7900HT SDS with the following thermal conditions: 2 min at $50^{\circ} \mathrm{C}, 10 \mathrm{~min}$ at $94.5^{\circ} \mathrm{C}, 40$ cycles of denaturation at $97^{\circ} \mathrm{C}$ for $30 \mathrm{sec}$ and annealing and extension at $59.7^{\circ} \mathrm{C}$ for $1 \mathrm{~min}$.

\section{Data analysis}

Quantitative real time PCR data were processed with SDS 2.1 software package $(\mathrm{AB})$. A defined baseline of 3 to 12 cycles and a defined threshold of 0.35 were used for all the genes to record the cycle thresholds (CTs). Since precision on TA starts dropping off at around 30-32 CTs, assays that yielded a CT > 31 cycles were excluded from the analysis and comparisons between PA and NPA genes were performed only taking into account those genes with a CT value $\leq 31$ in NPA samples (named validated genes). Data normalization was carried out with reference gene GUSB.

Linear regression analysis was performed to compare gene expression data $(\Delta \mathrm{CT})$ from NPA targets $\left(\Delta \mathrm{CT}_{\mathrm{NPA}}=\mathrm{CT}_{\mathrm{NPA}}\right.$ target $\left.-\mathrm{CT}_{\mathrm{NPA} G U S B}\right)$ vs PA targets $\left(\Delta \mathrm{CT}_{\mathrm{PA}}=\mathrm{CT}_{\mathrm{PA} \text { target }}-\mathrm{CT}_{\mathrm{NPA}}\right.$ GUSB). Those regressions with less than 4 points were excluded from the analysis. Specific gene preamplification uniformity was checked calculating the $\triangle \mathrm{CT}_{\mathrm{NPA}}$ and $\Delta \mathrm{CT}_{\mathrm{PA}}$, and determining the $\Delta \Delta \mathrm{CT}$ between NPA and PA targets $\left(\Delta \Delta \mathrm{CT}=\Delta \mathrm{CT}_{\mathrm{PA}}-\Delta \mathrm{CT}_{\mathrm{NPA}}\right) \cdot \Delta \Delta \mathrm{CT}$ values close to zero indicated preamplification uniformity. Targets that produce $\Delta \Delta$ CT values within \pm 1.5 were considered uniformly preamplified (TPAMMK Protocol, AB). AE of each assay was calculated from fluorescent data using the DART-PCR software version $1.0[20,21]$. Pfaffl (2001) definition for AE has been used [22].

\section{Competing interests}

The authors declare that they have no competing interests.

\section{Authors' contributions}

All authors participated in study concept, design and interpretation of data. LM carried out the experiments, participated in acquisition and analysis of data and drafting of the manuscript. MB participated in analysis of data, provided statistical expertise and critical revision of the manuscript. MM-A participated in collection of samples, assisted some experiments and critical revision of the manuscript. MJR participated in collection of samples, provided clinical expertise and critical revision of the manuscript. AA provided clinical expertise, critical revi- sion of the manuscript, obtained funding and supervised conduct of the study. All the authors have read and approved the final manuscript.

\section{Acknowledgements}

This research was partly supported by grants from the Spanish Urological Association (FIU 2007) and from Fondo de Investigaciones Sanitarias (PI070040) and by private funding (Laboratorios FINA BIOTECH). Advice from Dr María Luisa Checa is gratefully acknowledged. We thank Jon Sherlock for the critical revision of the manuscript and Helena Kruyer for the English correction of the manuscript. We also thank Dr. Dolors Colomer for her assistance in the Real Time PCR management.

\section{References}

I. Goulter AB, Harmer DW, Clark KL: Evaluation of low density array technology for quantitative parallel measurement of multiple genes in human tissue. BMC Genomics 2006, 7:34.

2. Tran DC, Brazeau DA, Fung HL: Determination of nitric oxidedonor effects on tissue gene expression in vivo using lowdensity gene arrays. Methods Enzymol 2005, 396:387-395.

3. Seth D, Gorrell MD, McGuinness PH, Leo MA, Lieber CS, McCaughan GW, Haber PS: SMART amplification maintains representation of relative gene expression: quantitative validation by real time PCR and application to studies of alcoholic liver disease in primates. J Biochem Biophys Methods 2003, 55:53-66.

4. Provenzano M, Mocellin S: Complementary techniques: validation of gene expression data by quantitative real time PCR. Adv Exp Med Biol 2007, 593:66-73.

5. Wang $Y$, Barbacioru CC, Shiffman D, Balasubramanian S, lakoubova O, Tranquilli M, Albornoz G, Blake J, Mehmet NN, Ngadimo D, Poulter K, Chan F, Samaha RR, Elefteriades JA: Gene expression signature in peripheral blood detects thoracic aortic aneurysm. PLoS ONE 2007, 2:el050.

6. Barrachina M, Moreno J, Juves S, Moreno D, Olive M, Ferrer I: Target genes of neuron-restrictive silencer factor are abnormally up-regulated in human myotilinopathy. Am J Pathol 2007, I71:1312-1323.

7. Okamoto N, Chihara R, Shimizu C, Nishimoto S, Watanabe T: Artificial lymph nodes induce potent secondary immune responses in naive and immunodeficient mice. J Clin Invest 2007, I I 7:997-1007.

8. Denning KM, Smyth PC, Cahill SF, Finn SP, Conlon E, Li J, Flavin RJ, Aherne ST, Guenther SM, Ferlinz A, O'Leary J], Sheils OM: A molecular expression signature distinguishing follicular lesions in thyroid carcinoma using preamplification RT-PCR in archival samples. Mod Pathol 2007, 20: 1095-I I02.

9. Dafforn A, Chen P, Deng G, Herrler M, Iglehart D, Koritala S, Lato S, Pillarisetty S, Purohit R, Wang M, Wang S, Kurn N: Linear mRNA amplification from as little as $\mathbf{5}$ ng total RNA for global gene expression analysis. Biotechniques 2004, 37:854-857.

10. Xiang CC, Chen M, Kozhich OA, Phan QN, Inman JM, Chen Y, Brownstein MJ: Probe generation directly from small numbers of cells for DNA microarray studies. Biotechniques 2003, 34:386-3.

II. Marko NF, Frank B, Quackenbush J, Lee NH: A robust method for the amplification of RNA in the sense orientation. $B M C$ Genomics 2005, 6:27.

12. Mengual L, Burset M, Ars E, Ribal MJ, Lozano JJ, Minana B, Sumoy L, Alcaraz A: Partially Degraded RNA from Bladder Washing is a Suitable Sample for Studying Gene Expression Profiles in Bladder Cancer. Eur Urol 2006, 50:1347-1356.

13. Max N, Wolf K, Spike B, Thiel E, Keilholz U: Nested quantitative real time PCR for detection of occult tumor cells. Recent Results Cancer Res 200I, I 58:25-31.

14. Bittman B, Berk L, Shannon M, Sharaf M, Westengard J, Guegler KJ, Ruff DW: Recreational music-making modulates the human stress response: a preliminary individualized gene expression strategy. Med Sci Monit 2005, I I:BR3I-BR40.

15. Cronin M, Pho M, Dutta D, Stephans JC, Shak S, Kiefer MC, Esteban JM, Baker JB: Measurement of gene expression in archival paraffin-embedded tissues: development and performance of a 
92-gene reverse transcriptase-polymerase chain reaction assay. Am J Pathol 2004, 164:35-42.

16. Fleige $S$, Pfaffl MW: RNA integrity and the effect on the realtime qRT-PCR performance. Mol Aspects Med 2006, 27: I 26- I39.

17. Sobin LH, Wittekind CH: TNM Classification of Malignant Tumours. International Union Against Cancer. 6th edition. New York, Jonh Wiley \& Sons; 2002.

18. Lopez-Beltran A, Sauter G, Gasser T, Hartmann A, Schmitz-Dräger B], Helpap B, Ayala AG, Tamboni P, Knowles MA, Sidransky D, Cordon-Cardo C, Jones PA, Cairns P, Simon R, Amin MB, Tyczynsky JE: Tumours of the Urinary System. In Pathology and Genetics of Tumours of the Urinary System and Male Genital Organs. World Health Organization Classification of Tumours. Edited by: Eble JN, Sauter G, Epstein JI and Sesterhenn IA. Lyon, IARC Press; 2004:89-I57.

19. Imbeaud S, Graudens E, Boulanger V, Barlet X, Zaborski P, Eveno E, Mueller O, Schroeder A, Auffray C: Towards standardization of RNA quality assessment using user-independent classifiers of microcapillary electrophoresis traces. Nucleic Acids Res 2005, 33:e56.

20. Peirson SN, Butler JN, Foster RG: Experimental validation of novel and conventional approaches to quantitative real-time PCR data analysis. Nucleic Acids Res 2003, 31 :e73.

21. Gene quantification 2008 [http://www.gene-quantification.de/ download.html].

22. Pfaff MW: A new mathematical model for relative quantification in real-time RT-PCR. Nucleic Acids Res 200I, 29:e45.

\section{Publish with Bio Med Central and every scientist can read your work free of charge}

"BioMed Central will be the most significant development for disseminating the results of biomedical research in our lifetime. "

Sir Paul Nurse, Cancer Research UK

Your research papers will be:

- available free of charge to the entire biomedical community

- peer reviewed and published immediately upon acceptance

- cited in PubMed and archived on PubMed Central

- yours - you keep the copyright

Submit your manuscript here:

http://www.biomedcentral.com/info/publishing_adv.asp 